\title{
Retraction Note: LncRNA miR503HG interacts with miR-31-5p through multiple ways to regulate cancer cell invasion and migration in ovarian cancer
}

\author{
Ding Zhu' ${ }^{1}$ Xueshuang Huang ${ }^{2^{*}}$ (D), Fang Liang ${ }^{1}$ and Lijing Zhao ${ }^{1}$
}

\author{
Retraction Note: J Ovarian Res 13, 3 (2020) \\ https://doi.org/10.1186/s13048-019-0599-9
}

The Editor-in-Chief has retracted this article [1] due to lack of evidence that the study has received ethics approval. After publication it has come to the Editor's attention that in the body of the article the authors state that their study was approved by the Ethics Committee of Hunan University of Medicine. However, in the Ethics declarations section, the authors state that their study was approved by the Ethics Committee of the Maternity and Child Care Center of Liuzhou. The authors have not provided documentation of approval from an ethics committee for this study. The authors agree with this retraction.

\section{Author details}

'Department of Gynecology, Hunan Provincial People's Hospital, Changsha City, Hunan Province 410005, People's Republic of China. ${ }^{2}$ Biomedical Research Center, Hunan University of Medicine, No.492 Jinxi South Road, Huaihua City, Hunan Province 418000, People's Republic of China.

Published online: 01 February 2021

\section{Reference}

1. Zhu D, Huang $X$, Liang F, et al. LncRNA miR503HG interacts with miR-31-5p through multiple ways to regulate cancer cell invasion and migration in ovarian cancer. J Ovarian Res. 2020;13:3. https://doi.org/10.1186/s13048-0190599-9.

* Correspondence: xueshuang878@aliyun.com

${ }^{2}$ Biomedical Research Center, Hunan University of Medicine, No.492 Jinxi South Road, Huaihua City, Hunan Province 418000, People's Republic of China

(c) The Author(s). 2020 Open Access This article is licensed under a Creative Commons Attribution 4.0 International License, which permits use, sharing, adaptation, distribution and reproduction in any medium or format, as long as you give appropriate credit to the original author(s) and the source, provide a link to the Creative Commons licence, and indicate if changes were made. The images or other third party material in this article are included in the article's Creative Commons licence, unless indicated otherwise in a credit line to the material. If material is not included in the article's Creative Commons licence and your intended use is not permitted by statutory regulation or exceeds the permitted use, you will need to obtain permission directly from the copyright holder. To view a copy of this licence, visit http://creativecommons.org/licenses/by/4.0/. The Creative Commons Public Domain Dedication waiver (http://creativecommons.org/publicdomain/zero/1.0/) applies to the data made available in this article, unless otherwise stated in a credit line to the data. 